\title{
Fabrication and Recording Properties of Shielded Planar Type Single Pole Write Head
}

\author{
K. Ise, T. Kiya, K. Taguchi, M. Uchida, and K. Yamakawa \\ AIT, Akita Prefectural R\&D Center, 4-21 Sanuki, Araya, Akita, 010-1623, Japan
}

\begin{abstract}
We fabricated a shielded planar single-pole write head that combined a tapered main pole to obtain a strong write head field and a wraparound shield to obtain a steep head-field distribution. Anisotropy etching pits of Si were used as a template to fabricate the new head, and magnetic yoke material was embedded in the template to form the tapered main-pole tip. As a result, this new head could be fabricated using a novel technique that is different from that used for present recording heads. Our first test recording with the head was successful.
\end{abstract}

Key words: shielded planar head, perpendicular recording, single-pole head, tapered main pole

\section{シールドプレーナ型単磁極ヘッドの作製と記録特性}

伊勢和幸・木谷貴則・田口香・内田勝・山川清志

秋田県産業技術総合研究センター高度技術研究所，秋田県秋田市新屋町字砂奴寄 4-21（テ010-1623）

\section{1. はじめに}

次世代の超高密度垂直磁気記録用の単磁極型記録ヘッドにおい ては，記録磁界強度の確保とその記録磁界の急峻化との両立が必 要不可欠とされる．記録磁界の急峻化に関しては，主磁極のトレ ーリング側1)や両サイド, あるいはその両方にシールドを付与する ことによる磁界の急峻化が試みられ，実際の単磁極型ヘッドにも 応用されている. しかしながら, このようなシールド構造は, フ リンジング磁界等の余分な磁界のみならず，適切に付与しなけれ ば記録過程に必要な磁界の一部も吸収して磁界強度の低下にもつ ながる，従って，今後の高密度化を見据えた場合には，いかに強 磁界強度を確保していくかがより重要になってくるものと考えら れる，その強磁界強度の確保に関しては，強い磁界強度を得る主 磁極構造として, テーパー型の主磁極構造2)などが提案されている 我々においても複合磁極面構造 3) という後段の磁極面からの磁界 が先端の磁極面の磁界に重畳することによって，主磁極材料の飽 和磁束密度を超えるような強い磁界強度を実現できる可能性のあ る構造を提案している. この様に強磁界を発生させるための主磁 極構造は，一般的に 3 次元的に複雑な形状をしているために，現 行の薄膜磁気ヘッドの様に，主に 2 次元平面でパターン化された 薄膜を積層していく作製プロセスで形成することは決して容易な ことではなく，実際の薄膜磁気へッドとしての報告例は少ない. 従って，実際に実現可能な構造とその作製方法を提案することは 極めて重要である．我々は複合磁極面構造とシールド構造とを共 に実現するへッドの基本的な構造として, プレーナ型構造 し，これを適用したシールドプレーナ型単磁極へッド5,6)を提案し ている. 本報告では，このシールドプレーナ型単磁極へッドにつ いて, 実際に試作を行ったので，その作製方法についての詳細と， 試作したヘッドの記録特性評価の一例について報告する.

\section{2. ヘッド構造}

今回試作を行ったシールドプレーナ型単磁極ヘッドの断面設計 図を Fig.1に示寸. 本ヘッドの主磁極は, 先端突起部が平らになっ た四角錐形状の先端部分と，その奥の四角柱の磁極部分で構成さ
れ，さらにその周囲にはコイルが巻かれている. リターンヨーク は主磁極の後端に接し，コイル全体を覆う様に配置される．シー ルドヨークは，主磁極のテーパー面に対して平行な端部を有し， その主磁極先端の四方を同一のギャップ長で取り囲んでいる. 試 作へッドの設計寸法は, 主磁極先端部が $1 \mu \mathrm{m}$ 角, 主磁極先端の 奥の四角柱の磁極は $5 \mu \mathrm{m}$ 角 $\times$ 高さ $2 \mu \mathrm{m}$, リターンヨークは 34 $\mu \mathrm{m} \times 37 \mu \mathrm{m} \times$ 厚さ $0.6 \mu \mathrm{m}$ である. コイルの断面は $2 \mu \mathrm{m} \times 0.5 \mu \mathrm{m}$, ピッチは $4 \mu \mathrm{m}$ で, 1 層当たり 3 ターンの 2 層構成である. これら の寸法は, 従来から報告している磁界計算のモデル7)よりも大きく， 特に平面寸法は 3 倍ほど大きい. これは今回の試作がプロセス構 築と基本動作確認を主たる目的としているためであり, 現在の 我々のプロセスの成熟度を考慮して, 安定に試作できる寸法精度 で設計を行ったためである. そのために，これまでに三次元有限 要素法による磁界計算で最適化を行ってきた理想の寸法に比べて 余裕のある寸法であることから, 今回の試作へッドの記録感度が ある程度犠牲になることはその磁界計算からも見積もられる.

\section{3. ヘッド作製}

本シールドプレーナ型単磁極ヘッドの試作に際して, 現行の薄 膜磁気ヘッドの作製では通常用いない様ないくつかの手法を用い ている. 一つは, Si 基板を化学的異方性エッチングして形成した エッチング溝をテンプレートとして用いて, 3 次元形状のテーパー 構造を持つ主磁極先端部を作製する手法である．もう一つは，主 磁極-シールド間ギャップ長とシールド高さを，製膜する厚さによ って自己整合的に形成する手法である. Fig.2 に本へッドの基本的

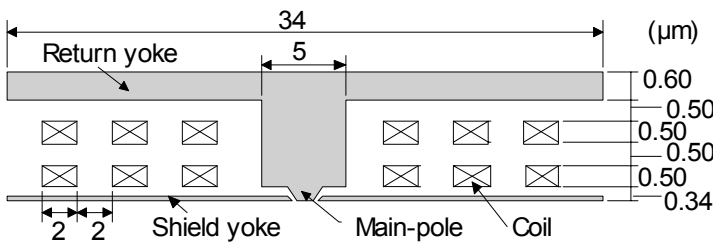

Fig. 1 Specifications for prototype shielded planar single-pole head . 
な作製プロセスの概念を示寸.今回のヘッド試作は，この作製プ ロセスを元に行ったので，その詳細を以下に記す。

1）へッド素子を形成する基板には，単結晶の $\operatorname{Si}(100)$ 基板を用い た. 初めにこの Si 基板に化学的異方性エッチングを行うためのマ スクを形成する．マスクの材料には，後述のエッチング溶液に対 して而性のある $\mathrm{SiO}_{2}$ や $\mathrm{Si}_{3} \mathrm{~N}_{4}$ 等を用い, 主磁極先端部のテンプレ 一トに適切な寸法・形状のマスク開口部を設ける.

2) $\mathrm{Si}_{3} \mathrm{~N}_{4}$ 等のマスクを設けた $\mathrm{Si}(100)$ 基板を, $80{ }^{\circ} \mathrm{C}$ 程度に加熱し た水酸化カリウム $(\mathrm{KOH})$ 溶液に浸漬して, 化学的な異方性エッチ ングを行う。この条件下では, $\mathrm{Si}$ の(100)面は毎分 1 2 $\mu \mathrm{m}$ 程度の 速度でエッチングされるが, (111)面のエッチング速度は(100)面の それと比べて桁違いに遅いことにより, 異方性エッチングが行わ れる. この時, エッチングによって形成される溝の側壁の角度は 54.7 度になる. 従って, 四角形状のマスクを用いて Si(100)基板を 異方性エッチングすることで, 前記 54.7 度のテーパー角を持つ四 角錐形状（ピラミッド形状）の溝のテンプレートを高精度に形成 することができる. この 54.7 度というテーパー角度は, 磁界計算 によって求めた強磁界強度と高磁界勾配とを両立する主磁極のテ 一パ一角の最適な值 7) とほぼ一致し， Si(100)基板を本へッドの試 作に用いることは適切であるといえる. Fig.3 に Si(100)基板の異 方性エッチングの例の SEM 像を示す.この様な手法を用いること により，基板全体に高精度に歩留まりよく，且つ，一括して微小 な主磁極形成用のテンプレートを形成できると考える.

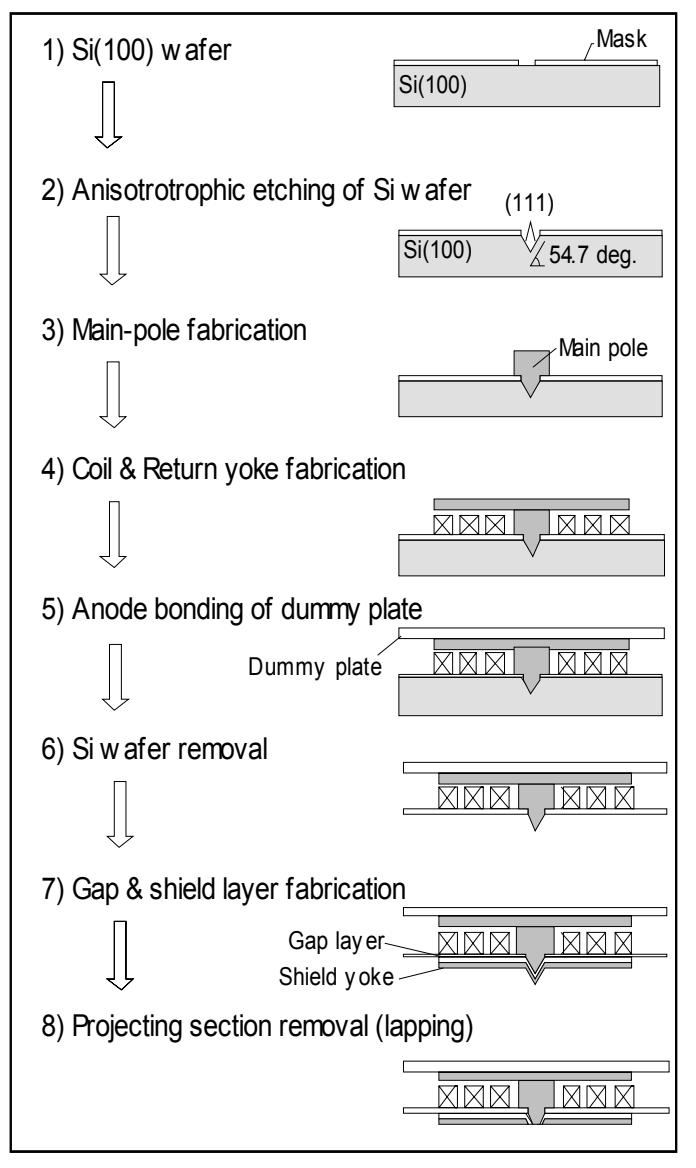

Fig. 2 Basic fabrication process for shielded planar single-pole head.
3）形成した $\mathrm{Si}$ のテンプレートに主磁極材料を埋め込むことで, 3 次元形状の主磁極先端部を形成する. 今回の試作において, ヘッ ドの主磁極材料には, 我々が以前検討していたカスプコイル励磁 型単磁極へッド(以下，カスプヘッドと記す)8)で実績のあるスパッ タで製膜した $\mathrm{Fe}-\mathrm{Si}$ 窒化膜を用いた. この $\mathrm{Fe}-\mathrm{Si}$ 窒化膜の磁気特性 は, 飽和磁束密度 $B_{\mathrm{s}}$ が $1.9 \mathrm{~T}$, 困難軸方向の保磁力 $H_{\mathrm{c}}$ が 2 Oe 以 下，異方性磁界 $H_{\mathrm{k}}$ が $8 \mathrm{Oe}$ 程度である.

4) 主磁極先端部の周囲にスパイラル状のコイル, 続いて絶縁層, 更にリターンヨークを順次形成していく.コイルは 2 層構成とし, 材料には $\mathrm{Au}$ を用い, 1 層当たりの巻き数は 3 ターンで, 全体では 6 ターンとした. また, リターンヨークの磁性膜には主磁極と同じ $\mathrm{Fe}-\mathrm{Si}$ 窒化膜を用いた. Fig.4に1層目のコイル, およびリターン ヨークをそれぞれ形成後のヘッド素子の写真を示寸.コイルの幅 とピッチはそれぞれ $2 \mu \mathrm{m}$ と $4 \mu \mathrm{m}$ とした. 上記のヘッドを構成す る各要素を形成後は，これらを保護する絶縁膜を製膜し，さらに その表面の平坦化研磨を行う。

5）素子を形成して絶縁膜表面を平坦化した $\mathrm{Si}$ 基板と，保護用の ガラス基板との接着を行う.この接着にはMEMS 開発などで用い られている陽極接合を用いた. 陽極接合は, 基板を $300 \sim 400{ }^{\circ} \mathrm{C}$ 程 度に加熱し, 基板間に $1 \mathrm{kV}$ 程度の電圧を印加することによって, ガラス中の電荷が分離を始めて, 負電荷が $\mathrm{Si}$ 側に引きつけられる 際に基板界面での静電力による吸引力で強力な接合が行われるも のである. 本試作においては, Si 基板の最表面は絶縁物で構成さ れるため, 導電層として Hf 膜 4$)$ を製膜し，これを電極として陽極 接合を行った. 接合した基板の様子を Fig.5 (a) に示す.一部, 接 合不良箇所であるボイドが若干見られるものの, 基板同士がほぼ 全面に渡って均一に接合できている. また，今回接合に用いたガ ラス基板には, MEMS 用途に用いられることが多く, 低膨長で低 温接合が可能な九旭テクノグラス製のセンサーガラス基板 SW-YY を用いて，磁生膜に影響が少ない低温で接合ができるようにした。 これにより，一般的なパイレックスガラスを用いた場合に比べて
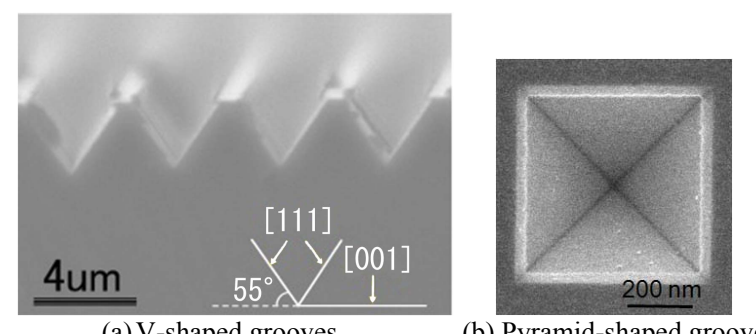

(b) Pyramid-shaped groove

Fig. 3 SEM images of grooves of $\mathrm{Si}(100)$ substrate after anisotropic chemical etching. (a) V-shaped and (b) Pyramid shaped.
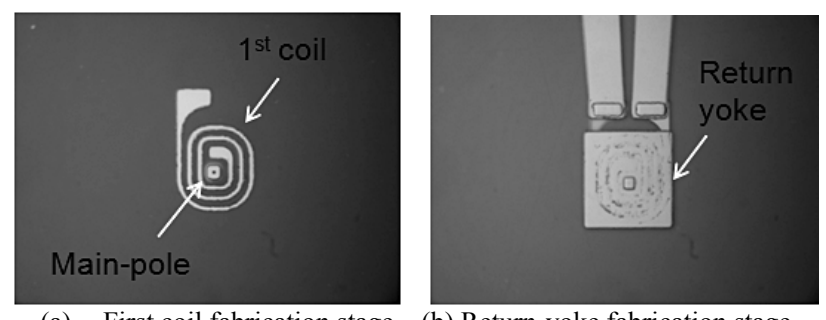

(a) First coil fabrication stage (b) Return-yoke fabrication stage Fig. 4 Photos of prototype head in process stages of (a) first coil fabrication, and (b) return-yoke fabrication. 
$50{ }^{\circ} \mathrm{C}$ 前後低温の $300{ }^{\circ} \mathrm{C}$ 程度で接合が可能であった. またこのセ ンサーガラス基板には，あらかじめ厚さ方向に炭酸ガスレーザー によって貫通孔を設けておいた. その貫通孔に陽極接合後, Si 基 板側から $\mathrm{Cu}$ の電解メッキ膜を成長させて, これを基板中に封入さ れたヘッド素子からの配線に用いた. 穴の直径が $100 \mu \mathrm{m}$ 強程度 に対し，穴の深さが $400 \mu \mathrm{m}$ 以上とアスペクト比が大きく，この 様な高アスペクト比の穴に良好な穴埋めメッキを行うために，今 回は穴埋めに適した添加剤（上村工業（株）提供）を用いて $\mathrm{Cu}$ の電解メッキを行った. その結果, 抵抗值の小さい良好な $\mathrm{Cu}$ の埋 め込みメッキを行うことを実現した. $\mathrm{Cu}$ の埋め込みメッキ後にガ ラス側に配線用端子を形成した基板の様子を Fig.5 (b) に示す.

6) 基板同士の陽極接合の後, $80{ }^{\circ} \mathrm{C}$ 前後の $\mathrm{KOH}$ 溶液に浸漬して, $\mathrm{Si}$ 基板の方をエッチングで完全に除去する. これにより, ヘッド 素子が保護用のガラス基板に転写・保持され, その最表面には四 角錐形状の主磁極先端部が出現する.

7）主磁極先端のある面に, ギャップ層とシールドヨーク層を製膜 する. この時の製膜した膜厚によって主磁極-シールド間ギャップ 長やシールド高さを規定するため, 精度良くその寸法を制御でき る. ただし, ギャップ長がダウントラック方向とクロストラック 方向で同一となるため, 最適化が必要である. 今回の試作では, ギャップ長とシールドの高さの值は磁界計算の結果を考慮して, どちらの值も $70 \mathrm{~nm}$ とした.

8）ギャップ層とシールドヨーク層を製膜後, 研磨により主磁極先 端の突出部を除去することでトラック幅を規定する. ヘッド素子 はその後, 我々においてカスプヘッド等でこれまでに実績のある スライディング・コンタクト方式で評価を行うために, ヘッド表 面に3点の摺動パッドを形成してコンタクトスライダーとした. パ ッドの高さは, 摺動型カスプヘッドで害績のある $5 \mu \mathrm{m}$ とした. その後, チップ切断とサスペンションへの取り付けを経て, 本へ ッドの試作を完了する.

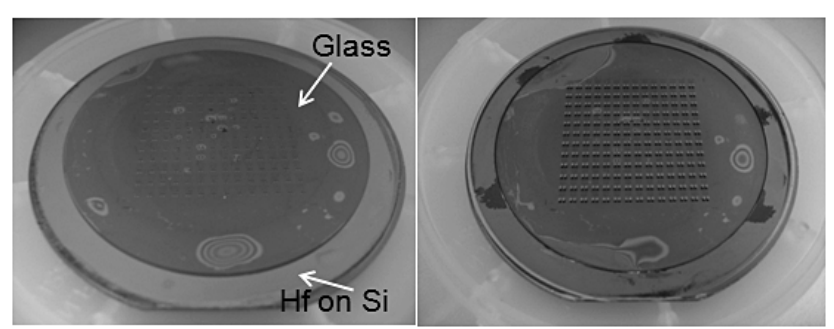

(a) Anode bonding stage

(b) Bonding-pad fabrication stage Fig. 5 Photos of prototype head wafer at various process stages.

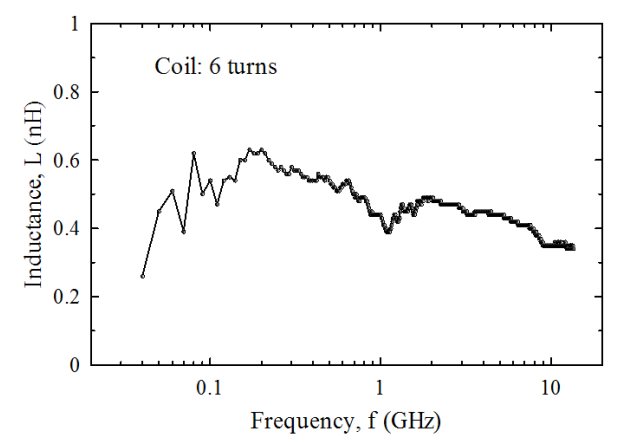

Fig. 6 High-frequency inductance of prototype head.
今回試作したヘッドの直流抵抗は $40 \Omega$ 程度で, インダクタンス は Fig.6 に示寸ように $0.6 \mathrm{nH}$ 程度であった. 以前に検討を行って いた実効的なコイル数が 3 ターンのカスプヘッドでは, そのイン ダクタンスは $1.5 \mathrm{nH}$ 程度であった. カスプヘッドの $1.5 \mathrm{nH}$ のイ ンダクタンスの内, その 3 分の 2 はコイル自体ではなく, リード 部分の影響であることが計算からわかっている. 一方，プレーナ ヘッドでは, リード部の長さは貫通孔配線も含めるとカスプヘッ ド以上に長く, また, コイルと鎖交する磁極コアの断面寸法もカ スプヘッドとほぼ同程度である. プレーナヘッドの方がコイル数 が多いのにもかかわらずカスプヘッドよりインダクタンスが低い のは, コイル径が小さいことによって磁気コアを伴わないコイル 自身のインダクタンスが低いためと推測され, 寸法を小型化・最 適化するなどの改良で更に低减が可能と予想される.

\section{4. 記録特性評価}

試作したシールドプレーナ型単磁極ヘッドの記録性能の評価を 行った. 今回試作したヘッドは記録へッド素子のみであるため, 記録特性評価は 2 ステージのスピンスタンドシステムを用いて, 記録再生分離で行った. 先に記したように, 試作したヘッドは 3 点パッドの摺動型のスライダーに加工し，これをねじれ剛性の高 い平行リンク型のサスペンションに取り付けて, スライディン グ・コンタクト方式で評価を行った. トラック幅は設計值で $1 \mu \mathrm{m}$, コイル巻き数は 6 ターンである. 試作へッドの摺動パッド付近の 素子の様子を Fig.7 に示す. 主磁極の周囲にギャップを介してシー ルドが四方に配置されていることがわかる. 再生には市販の TMR 型の垂直記録用ヘッドを用い，記録媒体には厚さ $35 \mathrm{~nm}$ の Co-Cr-Pt 記録層を有する垂直記録媒体を用いた．媒体の保磁力 $H_{\mathrm{c}}$ および飽和磁界 $H_{\mathrm{s}}$ はそれぞれ $3.9 \mathrm{kOe}$ および $8 \mathrm{kOe}$ である.

Fig.8 に試作したヘッドで記録し, 市販の垂直へッドで再生した 時の線記録密度 $40 \mathrm{kFCI}$ における再生波形を示す.このように提 案およひ試作を行ったシールドプレーナ型単磁極へッドで記録が できることを初めて実証することができた. Fig.9 に線記録密度 $100 \mathrm{kFCI}$ での飽和特性を示す. 今回測定に使用した飽和磁界 $H_{\mathrm{s}}$ が $8 \mathrm{kOe}$ の垂直記録媒体に対しては, 記録電流で $50 \mathrm{~mA} 0 \mathrm{p}$ 程度, 記録起磁力にして 0.30 AT 0 -P 程度でほぼ飽和記録が可能である. 有 限要素法を用いた磁界計算の結果からは, 今回試作したヘッドの 寸法では, ヘッド磁界の強度が飽和するのに必要な記録起磁力は $0.20 \mathrm{AT}_{0} \mathrm{-P}$ 程度であり, 今回の記録感度の実測值は磁界計算から予

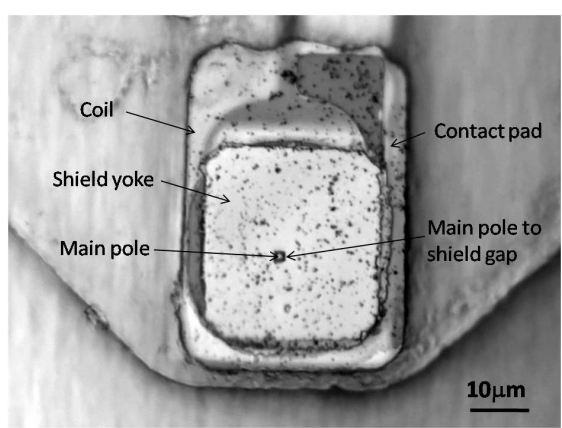

Fig. 7 Magnified photo of prototype head around main pole. 
測される範囲であると考える，ただし，計算から推測される結果 よりも若干記録感度が劣っている原因としては，作製プロセスに おける平坦化研磨などの工程において, 主磁極の高さが設計值よ りも低く加工され，その結果，主磁極の高さ方向での反磁界が増 大した影響などが考えられる. 今後, 作製精度を向上させること などにより改善できると考えられる.

また，オーバーライト特性は, Fig.10に示すように $30 \mathrm{~dB} よ り$ も若干低い值であった. 今回試作したヘッドの主磁極材料の飽和 磁束密度 $B_{\mathrm{s}}$ は $1.9 \mathrm{~T}$ 程度であり, 今後より高い $B_{\mathrm{s}}$ の主磁極材料を 用いることで改善が期待される. また，オフトラック特性を測定 したところ, 半值幅の值はトラック幅の設計值の 1 um とほぼ一致 していた. 本へッドの主磁極の奥, $300 \mathrm{~nm}$ ほど後退したところに はトラック幅よりも幅の広い $5 \mu \mathrm{m}$ 角の四角柱の磁極があること から，この磁極部分からの磁界が記録に影響寸る可能性もあった

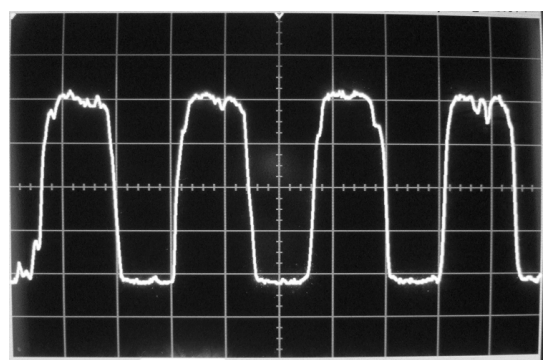

Fig. 8 Photo of read-back waveform at $40 \mathrm{kFCI}$.

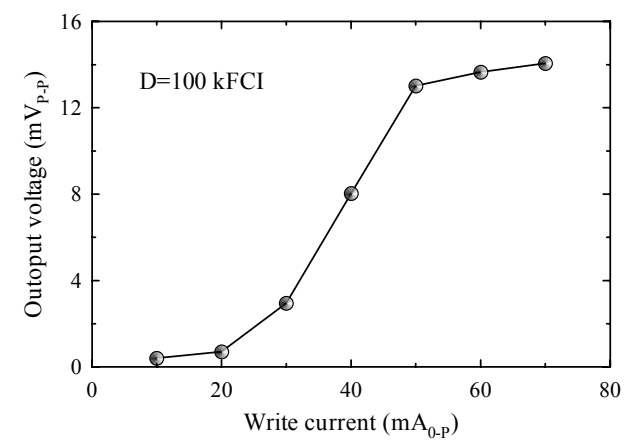

Fig. 9 Saturation curve at $100 \mathrm{kFCI}$.

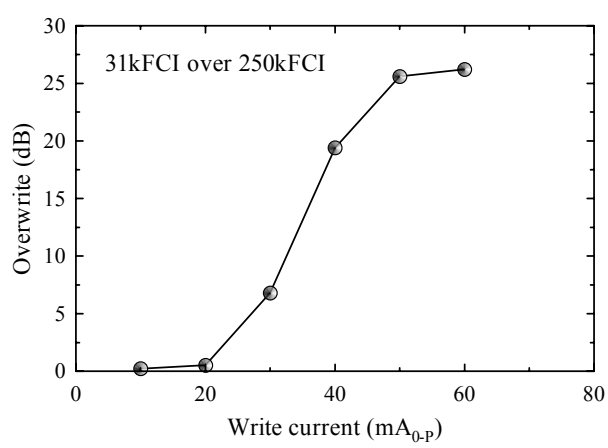

Fig. 10 Overwrite properties.
が，今回の測定結果からは特に影響は認められなかった. 今後, 主磁極卜ラックの物理的な幅の正確な測定を行った上で，主磁極 先端の四方に配置したラップアラウンド・シールドの記録にじみ に対する効果についての評価も行っていきたい.

\section{5. まとめ}

シールドプレーナ型単磁極ヘッドの試作検討を行った. ヘッドの試作には，現行の薄膜垂直へッドの作製には用い ることがないようないくつかの手法を用いて，1 回目の試 作を完成した．試作したヘッドの記録性能を評価したとこ ろ，試作したヘッドで記録した信号を市販の垂直ヘッドで 再生することができた. さらなる改善の余地はあるものの， 本シールドプレーナ型単磁極ヘッドが, 同時に提案した作 製方法で実現できることを実証できた.

本へッドにおける今後の課題としては，実用的な狭いト ラック幅でヘッドを実現し，その上で強磁界強度を得られ る複合磁極面構造の特徴を実証していくことにある.また, 実際の作製面においては，トラック幅が先端突出部の研磨 量に影響される問題などがある. 今後これらの課題に取り 組み, 複合磁極面構造やこれを取り入れたプレーナ構造の 単磁極へッドの優位性について実証し, 次世代の記録へッ ドとしての可能性を明らかにしていきたい.

謝辞 日頃よりご指導を賜ります AIT 名誉所長, 岩崎俊一 東北工業大学理事長に深謝致します. 日頃より有益なご助 言を賜ります大内一弘 AIT 名誉所長に感謝致します。本研 究の一部は独立行政法人新エネルギー・産業技術総合開発 機構の平成 17 年度産業技術研究助成事業により行われま した.

\section{References}

1) M. L. Mallary: US Patent, \#4 656 546, April 7, 1987. M. L. Mallary and S. C. Das, Reissued \#33 949 (1992).

2) M. Mochizuki, Y. Nishida, Y. Kawato, T. Okada, T. Kawabe, and H. Yakano: J. Magn. Magn. Mat., 235, 191 ( 2001).

3) S. Takahashi, K. Yamakawa and K. Ouchi: IEICE Tech. Rep. MR2001-1 (in Japanese), p.1 (2001).

4) D. W. Chapman: IEEE Trans. Magn., 25, 3686 (1989).

5) H. Yamada, K. Ise, S. Takahashi, K. Yamakawa and N. Honda: Digest of the $29^{\text {th }}$ annual conference on magnetic in japan(in Japanese), 20aA-3, p.135 (2005)

6) K. Ise, S. Takahashi, K. Yamakawa and N. Honda: IEEE Trans. Magn., 42, p.2422 (2006).

7) K. Yamakawa, K. Ise, S. Takahashi, N. Honda and K. Ouchi: IEICE Tech. Rep. MR2007-3 (in Japanese), p.13 (2007).

8) K. Ise, K. Yamakawa, N. Honda and K. Ouchi: IEEE Trans. Magn., 36, p.2520 (2000).

\section{8年10月21日受理，2009年3月4日採録}

